Apresentação

\section{O governo da Justiça \\ e os magistrados \\ no mundo}

\author{
luso-brasileiro
}

\author{
Isabele Mello [1]
}

Stuart Schwartz [2]
Resumo: Trata-se da apresentação do dossiê "O Governo da Justiça e os magistrados no mundo lusobrasileiro". O texto reflete brevemente a respeito da importância das análises sobre a dimensão humana da administração colonial, focando especialmente na magistratura, além de apresentar os textos que compõe o dossiê.

Palavras chave: Administração colonial, magistrados, magistratura, judiciário

\begin{abstract}
It is the presentation of the thematic number of Tempo, "Government of Justice and the magistrates in the Luso-Brazilian world". The text describes briefly the importance of the analysis of the human dimension of the Colonial Administration, focusing specially on the magistrates. Finally, it introduces the papers of the thematic number.
\end{abstract}

Keywords: Colonial administration, magistrates, magistracy, judiciary. 
A o apresentarmos a proposta do dossiê O governo da justiça e os magistrados no mundo luso-brasileiro para a Revista Tempo, no ano de 2016, pretendíamos reunir artigos que trouxessem novas perspectivas para a geração mais recente de historiadores interessados na temática. Nos últimos anos, após a retomada dos estudos sobre a administração colonial e seus principais agentes, um novo olhar vem sendo lançado sobre a história social das instituições jurídicas e dos magistrados. Esse renovado interesse pode ser facilmente identificado em razão do aumento gradativo de dissertações e teses sobre o tema, em diferentes programas de pós-graduação no Brasil, bem como em virtude de diversos eventos $^{3}$ e de publicações recentes ${ }^{4}$.

As novas pesquisas trilham de alguma forma o caminho aberto com a publicação da obra "Burocracia e sociedade no Brasil colonial". O trabalho de Stuart Schwartz, publicado originalmente em língua inglesa, no ano de 1973, e reeditado em 2011, foi produzido em um ambiente com grande carência de estudos sobre as instituições metropolitanas e das escassas pesquisas sobre a magistratura portuguesa ${ }^{5}$. Se, por um lado, a obra de Schwartz sempre representou uma contribuição fundamental para compreendermos o funcionamento do Império português - e suas reflexões acerca das relações entre a sociedade e o Estado serem amplamente difundidas no meio acadêmico brasileiro -, por outro, durante muitos anos sua proposta de olharmos com atenção para a dimensão humana da burocracia judicial permaneceu sem muito seguidores no Brasil.

Entretanto, a partir do incremento das pesquisas sobre a magistratura portuguesa e à luz de novas fontes disponíveis, aos poucos, o campo fértil de possibilidades analíticas, revelado por Stuart Schwartz há quase 40 anos, passou a conquistar novos adeptos. As questões observadas por Schwartz, como a importância do aparelho judicial para a administração, e a larga esfera de poder dos magistrados e sua influência na sociedade colonial, ainda hoje seguem chamando a atenção de um número cada vez maior de jovens pesquisadores brasileiros. Portanto, por inúmeras razões, sua obra, seja pela temática, seja pela metodologia ou pela discussão teórica, segue até hoje influenciando consideravelmente as pesquisas sobre o governo da justiça.

${ }^{3}$ Os eventos vêm ocorrendo em diferentes localidades do Brasil. Como exemplo podemos citar: o seminário A Justiça no Brasil Colonial (2015), organizado por Maria Fernanda Bicalho (UFF), Ronald Raminelli (UFF), Vírgínia Almôedo de Assis (UFPE) e Isabele Mello (UFF/CAPES), na Universidade Federal Fluminense; e o Colóquio Internacional Justiças, Governo e Bem Comum (2015), organizado por Júnia Ferreira Furtado (UFMG), Claúdia Atallah (UFF/Campos) e Patrícia Ferreira (UFMG), na Universidade Federal de Minas Gerais. Além disso, vale destacar que, desde a edição de 2014, o Encontro Internacional de História Colonial (EIHC) passou a contar com um simpósio temático denominado "O governo da justiça: poderes, instituições e magistrados (sécs. XVII-XIX)", coordenado por Antônio Filipe Pereira Caetano (UFAL) e Isabele Mello (UFF/CAPES).

${ }^{4}$ Entre as novas publicações podemos destacar: BICALHO, Maria Fernanda; ASSIS, Virgínia Maria Almoêdo de; MELLO, Isabele. "Justiça no Brasil Colonial. Agentes e práticas" (2017); MONTEIRO, Nuno Gonçalo; FRAGOSO, João. "Um Reino e suas Repúblicas no Atlântico" (2017), entre outras obras já citadas nos artigos do dossiê.

${ }^{5}$ Hoje, esse panorama já foi significativamente alterado, e temos contribuições importantíssimas de autores portugueses, como António Manuel Hespanha, Antônio Barbas Homem, José Subtil e, mais recentemente, Nuno Camarinhas. 
Aos poucos, mas em movimento crescente, dissertações, teses e estudos de casos, começam a revelar "os rostos" dos indivíduos nomeados para as diferentes instâncias jurídicas. Os novos trabalhos buscam compreender a organização da justiça no mundo luso-brasileiro, reavaliando e repensando o papel dos magistrados - juízes de fora, ouvidores e desembargadores - na construção e na manutenção do Império português. No jogo de poderes entre as forças reinóis contra os interesses locais na colônia, os magistrados constituíam a espinha dorsal da monarquia, mas ao mesmo tempo eles formaram um grupo poderoso, cujo interesses eram às vezes independentes. Servindo como representantes do poderio imperial e, ao mesmo tempo, como vetores de grupos ou indivíduos coloniais, o papel dos magistrados era central no funcionamento do império.

Assim, iniciamos o dossiê com um artigo de António Manuel Hespanha que nos brinda com uma exposição sobre o retrato social dos juristas por meio de um arguto exame de vários tratados de deontologia jurídica. Sua análise coloca para os historiadores a relevância de considerarmos nos estudos prosopográficos, o que denomina de contextualização ideográfica, ou seja, a consideração dos discursos que os juristas produziam sobre si próprios e sobre a sua atividade. As questões cuidadosamente tecidas por António Manuel Hespanha, autor cujas reflexões são referências primordiais para qualquer estudo sobre o governo da justiça e o mundo da magistratura no Antigo Regime, chamam atenção para a importância de incorporarmos a história do direito letrado na construção das pesquisas relacionadas à história social dos juristas.

No segundo artigo, Isabele Mello descortina o processo de criação dos três primeiros tribunais de justiça instituídos na América portuguesa. Sua pesquisa desvenda as motivações que levaram as áreas consideradas de vital importância desde o início da colonização - Bahia, Rio de Janeiro e Maranhão - a serem escolhidas como locais privilegiados para receber os tribunais da Relação. Nesse sentido, ao seguir o caminho já trilhado por Stuart Schwartze Arno Wehling, a autora nos traz uma análise inédita sobre o estabelecimento do Tribunal da Relação do Maranhão. Seu texto abre caminho para repensarmos o papel dos tribunais de justiça, tanto no âmbito do Estado do Brasil como no Estado do Maranhão, e busca uma melhor compreensão do funcionamento político e jurídico dessas instituições em relação à administração dos territórios.

O artigo de Patrícia Valim nos revela parte da atuação dos desembargadores do tribunal da Relação da Bahia na condução das devassas da Conjuração Baiana, destacando as complexas relações que poderiam ser forjadas entre os magistrados e o governador-geral na imbricada constelação de poderes do sistema administrativo da capitania. Em seu texto, a autora nos faz repensar a cultura jurídica do fim do século XVIII, bem como as possibilidades de ingerência dos governadores frente à indicação de desembargadores para realização de diferentes diligências no império ultramarino. 
Em seguida, o texto de Eduardo Borges aborda o processo de mobilidade social dos indivíduos nascidos na Capitania da Bahia, por meio de uma amostragem das leituras de bacharel realizadas ao longo do século XVIII. O autor nos mostra também como o pertencimento a um tribunal da Relação era uma mercê muito cobiçada, destaca a importância do estatuto de desembargador como capital simbólico almejado por parte da elite baiana, que buscou a distinção social pela via da carreira jurídica. A pesquisa realizada por Eduardo Borges aponta ainda para o número expressivo de indivíduos nascidos na Bahia, e provenientes das elites locais, que ingressaram na Universidade de Coimbra.

Finalizando o dossiê, temos o trabalho de Claúdia Atallah que discute uma outra faceta importante da organização judicial nos trópicos: a aplicação da justiça régia nas capitanias donatariais, vertente ainda pouco explorada na historiografia brasileira. Com o interessante estudo de caso, centrado no processo de aquisição régia da Capitania da Paraíba do Sul dos Campos dos Goytacazes e na atuação do Ouvidor-Geral Matheus Nunes José de Macedo, seu texto nos apresenta a complexa trama de disputas de poder e de negociação entre os agentes régios e as elites locais. Além disso, expõe o papel fundamental do tribunal da Relação da Bahia como arbítrio na resolução dos conflitos entre diferentes autoridades locais.

Esperamos que o leitor encontre nas páginas a seguir textos que lhe permitam aprimorar seu conhecimento sobre a história da administração da justiça e o universo da magistratura. Este dossiê contribui para uma temática instigante e desafiadora de um campo de estudos cada vez mais fecundo de nossa historiografia que, por sua vez, está chamando a atenção, gradativamente, de um número maior de pesquisadores brasileiros. 